\title{
Esophageal lichen planus: An unusual cause of dysphagia in the elderly
}

\author{
Augusto Pinke Cruz Carbonari ${ }^{1 *} \odot$, Regina Rie Imada ${ }^{1}$, Romeu Nakamura ${ }^{1}$, Osvaldo Araki ${ }^{1}, K_{\text {elly }}$ Cristina ${ }^{1}$, \\ Marcelo Luiz Balancin² ${ }^{2}$ Roberto El Ibrahim² \\ 'Endoscopy Unit, Rede D’Or Hospital São Luiz - Unidade Itaim, São Paulo, SP, Brazil \\ 2Diagnóstika, São Paulo, SP, Brazil
}

\begin{abstract}
Case report
An 82-year-old man sought our service with oropharyngeal and esophageal dysphagia for solid foods for the preceding three months. He had a previous history of hypertension, diabetes and coronary angioplasty. Differential diagnoses were suspected, such as tumors, Zenker diverticulum, extrinsic structural lesions, cervical spondylosis, strictures, reflux and eosinophilic esophagitis. The patient was referred for upper endoscopy, which showed multiple ulcers and friable mucosa involving the upper esophagus and oropharynx, without changes in the distal esophagus, gastroesophageal junction, stomach and duodenum (Figure 1). Esophageal biopsies were obtained for histopathology, which revealed squamous epithelial hyperplasia with chronic T-cell lymphocytic infiltrate (CD4, CD8 positive) with interface aggression, apoptotic basal, covered by fibrinous exudate. There was no immunohistochemical evidence of viral or fungal infection. Due to this findings, the diagnosis of esophageal lichen planus (Figures 2 and 3 ) was confirmed. The patient was referred for specific treatment and remains asymptomatic at follow-up.
\end{abstract}

\section{Discussion}

Lichen planus (LP) is an idiopathic disorder, affecting $0.5 \%$ to $2 \%$ of the population, with clinical manifestation in the skin, nails, hair, genital and mucosal surface. ${ }^{1}$ Esophageal lichen planus (ELP) is a rare and under-recognized disorder, with less than 100 cases described in the literature since its first report in $1982 .{ }^{2}$ This disease affects more frequently middle-aged females and involves predominantly the proximal portions of the esophagus. It can present as dysphagia, odynophagia and food impaction, secondary to esophageal lesions and strictures.

Endoscopic findings include esophageal erosions, ulcers, friable mucosa, white papules, pseudomembranes and stenosis. Preservation of gastroesophageal junction in ELP is an important resource that helps in the differentiation of ELP and gastroesophageal reflux disease. ${ }^{3}$ Malignant transformation of ELP to squamous cell carcinoma has been reported in the literature; due to this fact, endoscopic surveillance is recommended. 4,5

Histological findings in the esophagus resemble those from oral mucosa and reflect chronic junctional inflammatory aggression mediated by mature $\mathrm{T}$ lymphocytes, which include a band-like lymphocytic infiltrate involving the superficial lamina propria and basal epithelium, besides basal layer degeneration with and apoptotic basal keratinocytes (Civatte bodies). ${ }^{6}$

ELP can be found in more than $50 \%$ of patients with proven mucocutaneous LP when clinical and pathologic 

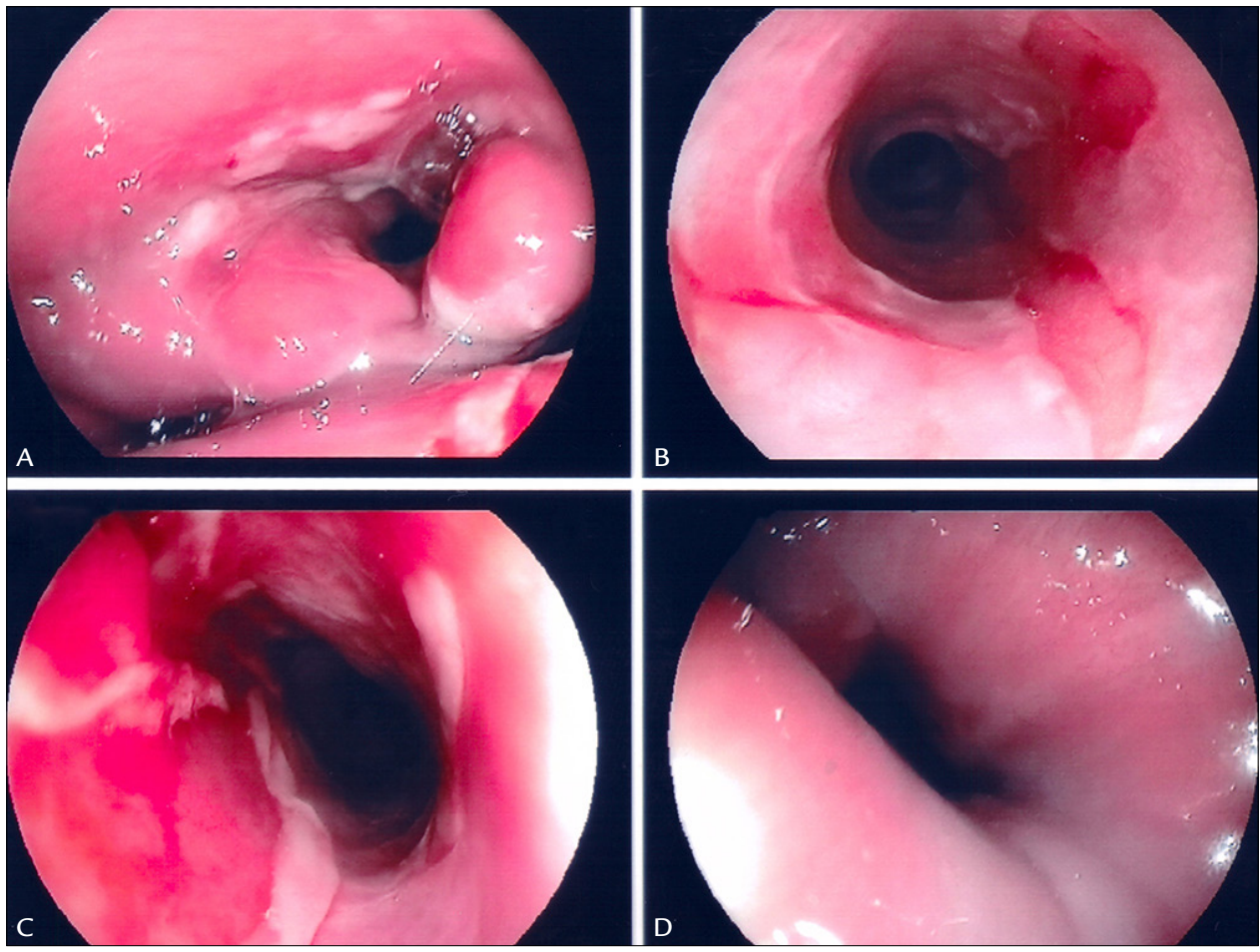

FIGURE 1 Endoscopic findings of esophageal lichen planus (multiple ulcers, friable mucosa), involving the oropharynx (A), the upper esophagus ( $B$ and $C$ ) and no changes in the distal esophagus and gastroesophageal junction (D).

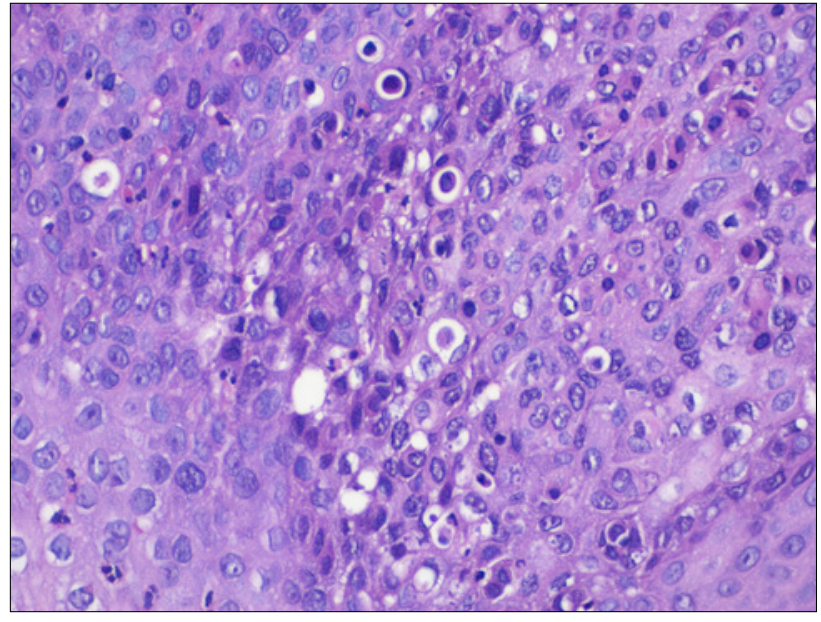

FIGURE 2 Pathology findings: esophageal basal layer with multiple Civatte bodies (apoptotic keratinocytes with anucleate remnants) (HE, x400).

findings are correlated carefully. ${ }^{7}$ Therapies for ELP include systemic and topical corticosteroids, cyclosporine, azathioprine and systemic retinoids. In cases of strictures, endoscopic treatment with dilation may be necessary. ${ }^{8}$ The correct clinical suspicion of this disease can facilitate the diagnosis and guide specific treatment, which can drastically change the natural course of the disease.

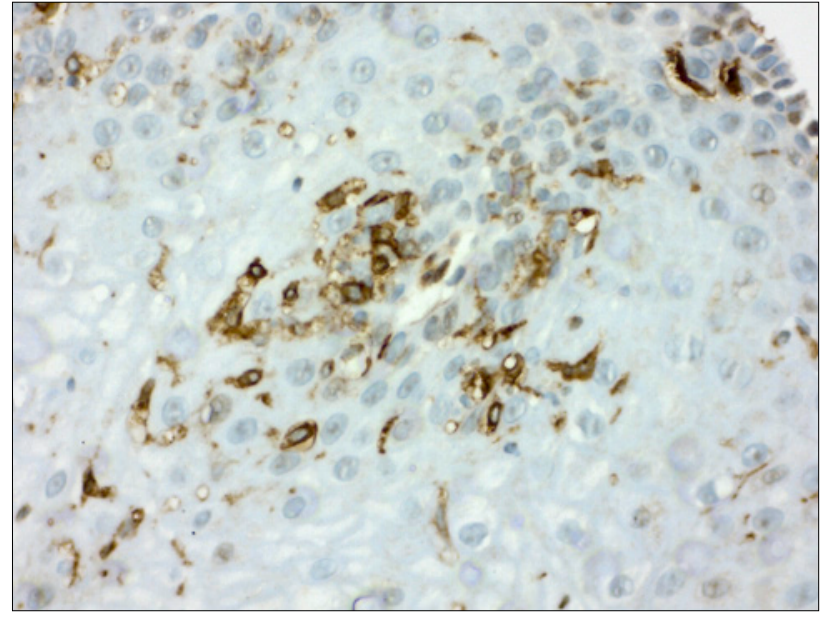

FIGURE 3 Pathology findings: CD4 lymphocytes evidenced by immunophenotype through immunohistochemistry (IHC, x400).

\section{Conflict of interest}

The authors declare no conflict of interest.

\section{Resumo}

Líquen plano esofágico: uma causa incomum de disfagia em idosos 
Paciente do sexo masculino, de 82 anos, com disfagia, foi encaminhado para realização de endoscopia digestiva alta com biópsias, na qual foram evidenciadas múltiplas úlceras de esôfago e orofaringe. O estudo histopatológico confirmou o diagnóstico raro de líquen plano esofágico. A correta suspeita clínica dessa doença pode facilitar o diagnóstico e direcionar para um tratamento específico, o que pode drasticamente alterar o curso natural dessa comorbidade.

Palavras-chave: Transtornos de Deglutição. Líquen Plano. Idoso.

\section{REFERENCES}

1. Fox LP, Lightdale CJ, Grossman ME. Lichen planus of the esophagus: what dermatologists need to know. J Am Acad Dermatol. 2011;65(1):175-83.
2. Al-Shihabi BM, Jackson JM. Dysphagia due to pharyngeal and oesophageal lichen planus. J Laryngol Otol. 1982;96(6):567-71.

3. Oliveira JP, Uribe NC, Abulafia LA, Quintella LP. Esophageal lichen planus. An Bras Dermatol. 2015;90(3):394-6

4. Nielsen JA, Law RM, Fiman KH, Roberts CA. Esophageal lichen planus: a case report and review of the literature. World J Gastroenterol. 2013; 19(14):2278-81.

5. Calabrese C, Fabbri A, Benni M, Areni A, Scialpi C, Miglioli M, et al. Squamous cell carcinoma arising in esophageal lichen planus. Gastrointest Endosc. 2003;57(4):596-9.

6. Franco DL, Islam SR, Lam-Himlin DM, Fleischer DE, Pasha SF. Presentation, diagnosis, and management of esophageal lichen planus: a series of six cases. Case Rep Gastroenterol. 2015:9(2):253-60.

7. Kern JS, Technau-Hafsi K, Schwacha H, Kuhlmann J, Hirsch G, Brass V, et al. Esophageal involvement is frequent in lichen planus: study in 32 patients with suggestion of clinicopathologic diagnostic criteria and therapeutic implications. Eur J Gastroenterol Hepatol. 2016;28(12):1374-82.

8. Sica M, Zulli C, Manta R, Villanacci V, Conigliaro R, Bassotti G. One-shot balloon dilation of esophageal stricture due to unusual lichen planus localization. J Gastrointestin Liver Dis. 2016;25(4):427. 